part of the molecule from the sulphuric acid bound by the base appears a very remote possibility.

Aside from these arguments, it is possible that if adenine is the only precursor of vitamin $B_{1}$ in the nucleic acids, one might fail to find activity upon irradiating nucleic acids, but succeed in finding it upon irradiating adenine sulphate, either because of the higher concentration of the material capable of activation in adenine sulphate solutions, or because the chemical binding of adenine to other constituents might prevent its activation when a part of the nucleic acid molecule.

Francts F. Heyroth.

JoHN R. LOOFBOUROW.

Basic Science Research Laboratory, University of Cincinnati, Cincinnati, Ohio.

Nov. 30.

1 NATURE, 130, 741; 1932.

Heyroth and Loofbourow, J. Amer. Chem. Soc., 53, 3441; 1931. - Heyroth and Loofbourow, Bull. Bas. Sci. Res., 3, 237; 1931.

Heyroth, Bull. Bas. Sci. Res., 4, 119 ; 1932.

- Heyroth and Loof bourow, NÄTuRE, 130, 773; 1932

- Heyroth and Loofbourow, Bull. Bas. Sci. Res., 4, 35; 1932.

'Windaus, et al., Z. physiol. Chem., 204, 123; 1932:' Kinnersley, O'Brien and Peters, J. Physiol., 76, $17 P$; 1932.

\section{Meaning of Neoteny and Pædogenesis}

For a scientific term to be of value it is absolutely necessary that in all circumstances it should be used with strict regard for its definition; otherwise only confusion of thought and faulty argument can result. This should be obvious, but unfortunately some terms readily lend themselves to misuse. 'Pædo. genesis' and 'neoteny' are terms the definitions of which have been treated with very scant respect. Because of the confusion that has resulted it seems desirable that attention should be directed both to the origins of these words and to their real significance.

The term 'pædogenesis' was first proposed in 1866 by K. E. von Baer ${ }^{1}$ who was writing of the phenomena which had recently been observed in Miastor, and it is quite clear that he regarded pædogenesis as a form of parthenogenesis. The fact that von Baer regarded parthenogenesis as a form of asexual reproduction does not affect the definition.

O. Hamann ${ }^{2}$ (1891), when he described an Acanthocephalan which became sexually mature in the larval stage, was one of the first to misuse the term 'predogenesis'. This was noticed by Chun, ${ }^{3}$ who when defining 'dissogony' protested against Hamann's use of 'pædogenesis'. It may be noted here that Hamann was the first to propose the idea of evolution taking place on a large scale by means of 'pædogenesis', an idea which in a modified form finds favour with some modern authors, notably Prof. W. Garstang ${ }^{4}$ and Mr. G. R. de Beer. ${ }^{5}$

Kollmann ${ }^{6}$ was the first to use the term 'neoteny', and he used it to describe the phenomena which had been observed in the Amphibia. He distinguished between 'partial neoteny', which is said to occur when metamorphosis is delayed beyond the normal period, for example, the wintering of certain tadpoles; and 'total neoteny', which is found in the case of the Axolotl, where the animal retains its gills but becomes sexually mature.

'Neoteny' and 'pædogenesis' therefore indicate two distinct phenomena. In 'pædogenesis' a form of parthenogenesis is found, but in 'neoteny' we see a case of normal sexual reproduction. The distinction between the terms is clear cut and is of biological importance.
In re-defining the terms under discussion, Mr. de Beer has disregarded their origins and the definitions of their authors. So he uses 'neoteny' as a wide term which implies an alteration in the rate of development of the germen as compared with that of the somatic tissues: an idea which cannot be brought into line with Kollmann's views. This alteration may be brought about in a number of ways; if by the speeding up of the rate of ripening of the germen, that of the somatic tissues remaining constant, 'pædogenesis' will result, and Mr. de Beer considers that the most perfect cases of this are those of Miastor and Polystomum integerrimum; if the acceleration has not proceeded so far a case like that of the Axolotl will result. On this view all these cases are different aspects of the same phenomenon.

It is very doubtful whether the matter should be considered in this way; it would appear to be giving the status of a fundamental biological concept to the observed fact that in a few isolated cases in the animal kingdom the normal relation between the rates of ripening of the germen and of the somatic tissues, as judged by observations on the majority of closely related species, has become modified.

That such a state of affairs has been brought about by changes in the external environment is undoubted, and in the case of the Ctenophores described by Chun ${ }^{7}$ this is abundantly clear. It is impossible therefore to consider the sporadic occurrence of the early ripening of the germen as more than a fortuitous happening; and it would appear to be of more value to use the words 'pædogenesis' and 'neoteny' to distinguish forms of parthenogenesis and normal sexual reproduction respectively than to combine under them isolated examples having no biological relationship and drawn at random from all over the animal kingdom.

We are thus brought to the conclusion that the cases of the Axolotl, the Ctenophores and the Acan. thocephala are cases of 'neoteny', whilst 'pædogenesis' occurs only in the insects; the case of Polystomum integerrimum, in which the fusion of gametes is said to occur, must be regarded as 'neoteny' in an hermaphrodite animal.

To those who incline towards the view that evolution on a large scale has taken place by the process of the shortening of the ontogeny, it may be pointed out that in discussions on this subject the older definitions of 'pædogenesis' and 'neoteny' are of great importance, for it is obvious that if the ontogeny were to be shortened in a truly pædogenetic form sexual reproduction would be lost to that species.

In conclusion it must be noted that 'dissogony' must be regarded as a form of 'neoteny', Chun himself having compared the phenomenon which he had observed with the case of the Axolotl, and contrasted it with the phenomena seen in Miastor.

Department of Zoology,

University of Glasgow. Nov. 17.

1 Bull. Acad. Imp. Sci. St. Petersbourg, T.9.

2 Jena. Z. Naturw., Bd. 25.

3 "Festschrift z. siebenzigsten Geburtstage Rudolf Leuckarts". Leipzig.

"Quart. J. Micr. Sci., London. Vol. 72, 1929.

5 "Embryology and Evolution". Oxford, 1930.

"Verh. naturf. Ges. Basel, Bd. 7. von Neapel". Monographie I, Ctenophoren. 